\author{
UNIVERSIDADE DE SÃO PAULO \\ INSTITUTO DE GEOCIÊNCIAS
}

\title{
RELAÇÕES PALEOCLIMÁTICAS E PALEOAMBIENTAIS DURANTE O HOLOCENO NO LESTE DA AMAZÔNIA NA REGIÃO DA VOLTA GRANDE DO RIO XINGU
}

\section{RUDNEY DE ALMEIDA SANTOS}

\author{
Tese apresentada ao Programa \\ Geociências \\ (Geoquímica \\ e \\ Geotectônica) para obtenção do título de \\ Doutor em Ciências.
}

Área de concentração: Geotectônica

Orientador: Prof. Dr. Paulo Eduardo de Oliveira Coordenadora: Prof. Dra. Juliana de Moraes Leme Basso 


\section{RESUMO}

O leste da região amazônica é uma região ainda pouco explorada pela palinologia, sendo que algumas questões sobre o paleoclima e o paleoambiente ainda necessitam de respostas. Além disso, o conhecimento da vegetação de planícies de inundação é fundamental para o entendimento da formação e evolução das Florestas de Várzea e Igapó. O trabalho foi desenvolvido na porção leste da Amazônia na região da Volta Grande do Rio Xingu, município de Altamira no Estado do Pará. Foram coletados dois testemunhos intitulados XC06 - Lago Irirí $\left(3^{\circ} 48^{\prime}\right.$

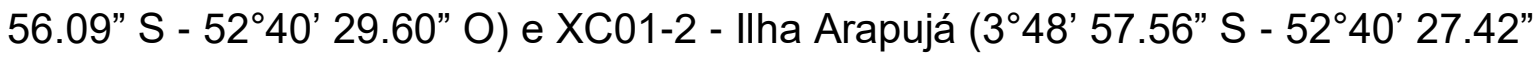
O). Os objetivos da pesquisa foram: Verificar a evolução da vegetação de várzea e igapó durante o Holoceno; investigar o possível evento seco durante o Holoceno Médio no leste da Amazônia; avaliar o clima que prevaleceu ao longo do perfil sedimentar e buscar evidências de alteração na paisagem relacionadas a atividades antrópicas. A técnica empregada para o desenvolvimento da pesquisa foram a palinologia, partículas carbonizadas, granulometria, XRF e isótopos $(\mathrm{C} / \mathrm{N}$, $\mathrm{NT}, \delta^{15} \mathrm{~N}$ e COT). Os resultados obtidos mostraram que a vegetação alcançou dois momentos de expansão e desenvolvimento sendo o primeiro em cerca de 8.700 anos cal. AP e o segundo cerca de 2.000 anos cal. AP. Oscilações na concentração de táxons polínicos, mostraram momentos de períodos de inundação prolongados que afetou diretamente a vegetação. Durante o Holoceno a região de estudo apresentou umidade sempre presente, o que revela a ausência de evento seco no Médio Holoceno em Altamira. Atividades antrópicas estão evidenciadas a partir de 1.900 anos cal. AP, pelo aumento de esporos, presença de vegetação característica de abertura de floresta e presença de vegetação de interesse humano como é o caso de Mauritia flexuosa (Buriti).

Palavras chaves: Amazônia; planície de inundação; Xingu; várzea; igapó; palinologia; Holoceno. 


\section{INTRODUÇÃO}

A Floresta amazônica é o maior ecossistema de Floresta tropical com cerca de 6 milhões de $\mathrm{km}^{2}$. Além de ser o ecossistema com maior biodiversidade, do planeta, abrigando cerca de 16.000 espécies de árvores (Ter Steege et al., 2013), a Amazônia desempenha um papel significativo na regulação do clima global (Cordeiro et al., 2008a). Por sua evidente importância para o clima global, entender a dinâmica da Floresta amazônica no passado, e como ela responderá frente as eminentes mudanças climáticas futuras, assim como estudos paleoambientais e paleoclimáticos, são de extrema importância.

A Palinologia do Quaternário, ou seja, o estudo de grãos de pólen e esporos de plantas preservados em sedimentos de lagos e bacias sedimentares representa uma das técnicas mais robustas para o entendimento das mudanças na vegetação, causadas por variações climáticas globais e locais (Salgado-Labouriau, 1973). Além disso, dados palinológicos, quando disponíveis na literatura científica, podem ser incorporados a análises climáticas, especialmente com intuito de validação de modelos climáticos, e assim, colaborar com projeções climáticas futuras (Marengo, 2006; Wozniak and Steiner, 2017). Também é importante ressaltar que estudos multiproxies sobre a vegetação e o clima em diferentes áreas possibilitam a integração de informações valiosas que quando interpretadas em conjunto, ajudam a elucidar particularidades de cada ecossistema, podendo interferir/colaborar no entendimento da dinâmica de ecossistemas distintos. Um exemplo de interação de estudos pode ser visto em estudos relacionados ao entendimento do sistema de monções (Wang et al., 2008). Tal fenômeno climático, na Bacia Amazônica, pode influenciar a dinâmica da precipitação e dos padrões locais de umidade em quase toda a América do Sul, ilustram a importância de estudos multiproxies (Cruz et al., 2009; Cheng et al., 2013; Wang et al., 2017).

Uma série de questões paleoclimáticas e paleoambientais foram levantadas para a Amazônia, afim de ter o melhor entendimento de como os ecossistemas reagiram perante as variações climáticas ao longo do tempo. O início e o médio Holoceno foram épocas de aumento do nível relativo do mar (Angulo et al., 2002), enfraquecimento do El Niño / Oscilação Sul (ENSO) (Conroy et al., 2008) e enfraquecimento da monção sul-americana (Prado et al., 2013). Não 
surpreendentemente, muitos desses eventos climáticos ressoam nos registros paleoecológicos dos neotrópicos. Um evento seco do Holoceno Médio causado pelo enfraquecimento da Monção de Verão da América do Sul ocorreu entre ca. 9.200 e 4.400 cal. anos AP (Prado et al., 2013). Em algumas regiões da Amazônia, estudos paleoambientais e paleoclimáticos indicam que no Holoceno Médio o clima foi relativamente seco e em alguns estudos foi observado que o nível de lagos diminuiu, como foi o caso no Morro dos Seis Lagos (Colinvaux et al., 1996) na região do Alto Rio Negro e Carajás (Cordeiro et al., 2011) entre outros. Por outro lado, alguns estudos apontam resultados diferentes para essas mesmas oscilações climáticas, formações de lagos e expansão de Florestas de Várzea e lgapó foram observadas no Lago Calado (Behling et al., 2001), Lago Curuçá (Behling and Lima Da Costa, 2001) e Lago Tapajós (Irion et al., 2006). No entanto, estudos em sedimentos com idades dentro do Holoceno Tardio, registraram aumento da frequência do sistema ENSO (Conroy et al., 2008) e retorno de condições climáticas úmidas na Amazônia (Mayle, 2000; Baker et al., 2001; Bush et al., 2004c; Cordeiro et al., 2011; Cohen et al., 2014; Reis et al., 2017).

Estudos paleoambientais e paleoclimáticos também colaboram com o entendimento do comportamento das primeiras ocupações humanas no continente, e as consequências dessas ocupações na composição e estrutura da vegetação da Bacia Amazônica (Heckenberger et al., 2008; McMichael et al., 2013; Piperno et al., 2015; Watling et al., 2017; Maezumi et al., 2018). Humanos estiveram na paisagem no Holoceno tardio, e provavelmente afetaram as populações de grandes mamíferos. Por exemplo, há evidências de que a caça de antas teria afetado a dispersão de sementes (Guimarães et al., 2008). Porém, qual a extensão espacial, a continuidade temporal e os efeitos destas alterações nos ecossistemas amazônicos são ainda pouco conhecidos.

Outra questão importante sobre o leste amazônico é a divergência de interpretações relacionadas ao período seco durante o Holoceno Inicial e Médio. Estudos de Cheng et al. (2013) e Wang et al. (2017) para a Caverna Paraíso mostram período de umidade para esse intervalo, já Absy et al. (1991), Cordeiro et al. (2008b, 2011) e Reis et al. (2017) na Serra de Carajás divergem dessa interpretação. Este trabalho trouxe novos dados que mostram as condições 
paleoambientais e paleoclimáticas para a região da Volta grande do Rio Xingu, afim de elucidar melhor como esteve a região durante o Holoceno. 


\section{CONCLUSÕES}

O presente estudo foi idealizado para trazer luz ao entendimento sobre o comportamento da vegetação de várzea e igapó da região da Volta Grande do Rio Xingu (VGRX) perante as variações climáticas ocorridas no setor leste da Amazônia durante o Holoceno. Os dados palinológicos, associados a análises geoquímicas granulométricas, evidenciaram que Floresta de Várzea e lgapó da VGRX, expandiu pela primeira vez por volta de 8.700 anos cal. AP e apresentou oscilações de concentração de táxons botânicos até cerca de 5.100 anos cal. AP. Em seguida, os perfis palinológicos apontam para uma redução da concentração polínica, relacionada provavelmente a longos períodos de inundação que persistiram até cerca de 2.000 anos cal. AP. Com o término dos dessa fase de cheia a Floresta de Várzea e Igapó sofreu o segundo estágio de inundação, que se mantém até o Presente.

O período de menor precipitação durante o Médio Holoceno, apontado por alguns estudos palinológicos, não está evidente na VGRX, pois a todo instante os dados denotam umidade sempre presente. Sobre essa questão, pode se afirmar que alguns registros palinológicos disponíveis na literatura chegam a interpretação de climas secos baseando-se principalmente no aumento de gramíneas e outras ervas, que são interpretadas erroneamente. E o caso das ervas da Família Poaceae, conhecida por possuir táxons adaptados a vida submersa no sistema de várzea e igapó da Amazônia.

Foram encontradas evidencias de ocupação humana na VGRX em cerca de 1.900 anos cal. AP, com base em elementos de sucessão ecológica impulsionada pela abertura antropogênica da paisagem, pois o aumento de esporos indicou abertura de floresta corroborado pela presença em grandes concentrações de táxons de vegetação primária e também aparecimento de táxons de interesse humano como é o caso de Mauritia flexuosa. A concentração de partículas carbonizadas, geralmente pequenas e de fácil transporte pelas correntes fluviais tem origem incerta. 


\section{REFERÊNCIAS BIBLIOGRAFICAS}

Abbott, M.B., Wolfe, B.B., Aravena, R., Wolfe, A.P., and Seltzer, G.O., 2000, Holocene hydrological reconstructions from stable isotopes and paleolimnology, Cordillera Real, Bolivia: Quaternary Science Reviews, v. 19, p. 1801-1820, doi:10.1016/S02773791(00)00078-0.

Absy, M.L. et al., 1991, Mise en évidence de quatre phases d'ouverture de la forêt dense dans le Sud-Est de l'Amazonie au cours des 60000 dernières années: Première comparaison avec d'autres régions tropicales: Comptes Rendus de l'Académie des Sciences, v. 312, p. 673-678, doi:10.1016/j.energy.2010.04.015.

Adrian Quijada-Mascareñas, J., Ferguson, J.E., Pook, C.E., Salomão, M.D.G., Thorpe, R.S., and Wüster, W., 2007, Phylogeographic patterns of trans-Amazonian vicariants and Amazonian biogeography: The Neotropical rattlesnake (Crotalus durissus complex) as an example: Journal of Biogeography, v. 34, p. 1296-1312, doi:10.1111/j.1365-2699.2007.01707.x.

Aleman, J.C. et al., 2013, Tracking land-cover changes with sedimentary charcoal in the Afrotropics: Holocene, v. 23, p. 1853-1862, doi:10.1177/0959683613508159.

Alvares, C.A., Stape, J.L., Sentelhas, P.C., De Moraes Gonçalves, J.L., and Sparovek, G., 2013, Köppen's climate classification map for Brazil: Meteorologische Zeitschrift, v. 22, p. 711-728, doi:10.1127/0941-2948/2013/0507.

Andrus, C.F.T., Crowe, D.E., Sandweiss, D.H., Reitz, E.J., and Romanek, C.S., 2002, Otolith $\delta 180$ record of mid-holocene sea surface temperatures in Peru: Science, v. 295, p. 1508-1511, doi:10.1126/science.1062004.

Angulo, R.J., Pessenda, L.C.R., and Souza, M.A., 2002, O Significado das Datações ao 14C na Reconstrução de Paleoníveis Marinhos e na Evolução das Barreiras Quaternárias do Litoral Paranaense: Revista Brasileira de Geociencias, p. 95-106.

Assis, R.L. de, 2008, Composição Floristica E Estrutura Da Regeneração Arbórea De Flroestas De Várzea Alta E Varzea Baixa Na Rds Mamiraua, Amazonia Central: 86 p.

Bahia, R.B.C., Faraco, M.T.L., Monteiro, M.A.S., and Oliveira, M.A.O., 2004, Folha SA.22Belém, in: Carta Geológica do Brasil ao Milionésimo, in Schobbenhaus, C., Gonçalves, J.H., Santos, J.O.S., Abram, M.B., Leão Neto, R., Matos, G.M.M., Vidotti, R.M., Ramos, M.A.B., and Jesus, J.D.A. de eds., Sistema de Informações Geográficas. Programa Geologia do Brasil, Brasilia, CPRM.

Baker, P.A., and Fritz, S.C., 2015, Nature and causes of Quaternary climate variation of 
tropical South America: Quaternary Science Reviews, v. 124, p. 31-47, doi:10.1016/j.quascirev.2015.06.011.

Baker, P.A., Fritz, S.C., Garland, J., and Ekdahl, E., 2005, Holocene hydrologic variation at Lake Titicaca, Bolivia/Peru, and its relationship to North Atlantic climate variation: Journal of Quaternary Science, v. 20, p. 655-662, doi:10.1109/DEXA.2005.140.

Baker, P.A., Seltzer, G.O., Fritz, S.C., Dunbar, R.B., Grove, M.J., Tapia, P.M., Cross, S.L., Rowe, H.D., and Broda, J.P., 2001, The History of South American: Science Reports, v. 291, p. 640-643, doi:10.1126/science.291.5504.640.

Baker, P.A., Seltzer, G.O., Fritz, S.C., Dunbar, R.B., Grove, M.J., Tapia, P.M., Cross, S.L., Rowe, H.D., and Broda, J.P., 2011, The History of South American Tropical Precipitation for the Past 25 , 000 Years: v. 640, p. 640-644, doi:10.1126/science.291.5504.640.

Balée, W., 2010, Contingent diversity on anthropic landscapes: Diversity, v. 2, p. 163-181, doi:10.3390/d2020163.

Balée, W., 1989, "The culture of Amazonian forests.": Advances in economic botany,.

Barlow, J., Gardner, T.A., Lees, A.C., Parry, L., and Peres, C.A., 2012, How pristine are tropical forests? An ecological perspective on the pre-Columbian human footprint in Amazonia and implications for contemporary conservation: Biological Conservation, v. 151, p. 45-49, doi:10.1016/j.biocon.2011.10.013.

Barlow, J., Haugaasen, T., and Peres, C.A., 2002, Effects of ground fires on understorey bird assemblages in Amazonian forests: Biological Conservation, v. 105, p. 157-169, doi:10.1016/S0006-3207(01)00177-X.

Barlow, J., and Peres, C.A., 2004, Ecological responses to El Niño-induced surface fires in central Brazilian Amazonia: Management implications for flammable tropical forests: Philosophical Transactions of the Royal Society B: Biological Sciences, v. 359, p. 367380, doi:10.1098/rstb.2003.1423.

Behling, H., and da Costa, M.L., 2000, Holocene Environmental Changes from the Rio Curuá Record in the Caxiuanã Region, Eastern Amazon Basin: Quaternary Research, v. 53, p. 369-377, doi:10.1006/qres.1999.2117.

Behling, H., and Hooghiemstra, H., 1999, Environmental history of the Colombian savannas of the Llanos Orientales since the Last Glacial Maximum from lake records El Pinal and Carimagua: Journal of Paleolimnology, p. 461-476, http://link.springer.com/article/10.1023/A:1008051720473 (accessed October 2014). 
Behling, H., Keim, G., Irion, G., Junk, W., and Nunes de Mello, J., 2001, Holocene environmental changes in the Central Amazon Basin inferred from Lago Calado (Brazil): Palaeogeography, Palaeoclimatology, Palaeoecology, v. 173, p. 87-101, doi:10.1016/S0031-0182(01)00321-2.

Behling, H., and Lima Da Costa, M., 2001, Holocene vegetational and coastal environmental changes from the Lago Crispim record in northeastern Pará State, eastern Amazonia: Review of Palaeobotany and Palynology, v. 114, p. 145-155, doi:10.1016/S0034-6667(01)00044-6.

Bernard, B.., Bernard, H., and Brooks, J.., 2004, Determination of Total Carbon, Total Organic Carbon and Inorganic Carbon in Sediments: TDI-Brooks International/B\&B Lab ..., p. 1-5, doi:10.1139/x01-052.

Bertassoli, D.J. et al., 2017, The Fate of Carbon in Sediments of the Xingu and Tapajós Clearwater Rivers, Eastern Amazon: Frontiers in Marine Science, v. 4, doi:10.3389/fmars.2017.00044.

Binotto, B., Paula, A., Graciele, A., Neumann, M., Luisa, T., and Budke, J.C., 2016, TOLERÂNCIA DE PLÂNTULAS DE Cedrela fissilis VELL. A DIFERENTES AMPLITUDES E INTENSIDADES DE INUNDAÇÃO: Ciência Florestal, v. 26, p. 1339_ 1348.

Bird, B.W., Abbott, M.B., Rodbell, D.T., and Vuille, M., 2011, Holocene tropical South American hydroclimate revealed from a decadally resolved lake sediment $\delta 180$ record: Earth and Planetary Science Letters, v. 310, p. 192-202, doi:10.1016/j.epsl.2011.08.040.

Blaauw, M., and Christeny, J.A., 2011, Flexible paleoclimate age-depth models using an autoregressive gamma process: Bayesian Analysis, v. 6, p. 457-474, doi:10.1214/11BA618.

Bond, G., Showers, W., Cheseby, M., Lotti, R., Almasi, P., DeMenocal, P., Priore, P., Cullen, H., Hajdas, I., and Bonani, G., 1997, A pervasive millennial-scale cycle in North Atlantic Holocene and glacial climates: Science, v. 278, p. 1257-1266, doi:10.1126/science.278.5341.1257.

Bush, M.B., 2002, On the interpretation of fossil Poaceae pollen in the lowland humid neotropics: Palaeogeography, Palaeoclimatology, Palaeoecology, v. 177, p. 5-17, doi:10.1016/S0031-0182(01)00348-0.

Bush, M.B., Oliveira, P.E. De, Colinvaux, P.A., Miller, M.C., and Moreno, J.E., 2004a, 
Amazonian paleoecological histories: One hill, three watersheds: v. 214, p. 359-393, doi:10.1016/j.palaeo.2004.07.031.

Bush, M.B., Silman, M.R., De Toledo, M.B., Listopad, C., Gosling, W.D., Williams, C., De Oliveira, P.E., and Krisel, C., 2007, Holocene fire and occupation in Amazonia: Records from two lake districts: Philosophical Transactions of the Royal Society B: Biological Sciences, v. 362, p. 209-218, doi:10.1098/rstb.2006.1980.

Bush, M.B., Silman, M.R., and Urrego, D.H., 2004b, 48,000 Years of Climate and Forest Change in a Biodiversity Hot Spot: Science, v. 303, p. 827-829, doi:10.1126/science.1090795.

Bush, M.B., Silman, M.R., and Urrego, D., 2004c, 48 , 000 Years of Climate and Forest Change in a Biodiversity Hot Spot Author ( $s$ ): Mark B. Bush, Miles R. Silman and Dunia H . Urrego Reviewed work ( $s$ ): Source: Science, New Series, Vol . 303 , No . 5659 , Mathematics in Biology ( Feb . 6 , 2004: Science, v. 303, p. 827-829.

Camarão, A.P., Filho, A.P. da S.S., and Marques, J.R.F., 2006, Gramíneas Forrageiras Nativas e Introduzidas de Terras Inundáveis da Amazônia:

CAMPBELL, D.G., STONE, J.L., and ROSAS, A., 1992, A comparison of the phytosociology and dynamics of three floodplain (Várzea) forests of known ages, Rio Juruá, western Brazilian Amazon: Botanical Journal of the Linnean Society, v. 108, p. 213-237, doi:10.1111/j.1095-8339.1992.tb00240.x.

Cardozo, A.Y.V., Gomes, D.F., da Silva, E.M., Duque, S.R.E., Rangel, J.O.C., Sifeddine, A., Turcq, B., and Albuquerque, A.L.S., 2014, Holocene paleolimnological reconstruction of a high altitude Colombian tropical lake: Palaeogeography, Palaeoclimatology, Palaeoecology, v. 415, p. 127-136, doi:10.1016/j.palaeo.2014.03.013.

Carim, M.D.J.V., 2016, Estrutura, composição e diversidade em florestas alagáveis de várzea de maré e de igapó e suas relações com variáveis edáficas e o período de inundação no Amapá, Amazônia Oriental, Brasil: INSTITUTO NACIONAL DE PESQUISAS DA AMAZÔNIA - INPA, 96 p.

Castro, J.W.A., Suguio, K., Seoane, J.C.S., Da Cunha, A.M., and Dias, F.F., 2014, Sealevel fluctuations and coastal evolution in the state of Rio de Janeiro, southeastern Brazil: Anais da Academia Brasileira de Ciencias, v. 86, p. 671-683, doi:10.1590/0001-3765201420140007.

CATTANIO, J.H., ANDERSON, A.B., and CARVALHO, M.S., 2002, Floristic composition 
and topographic variation in a tidal floodplain forest in the Amazon Estuary: Revista Brasileira de Botânica, v. 25, p. 419-430, doi:10.1590/S0100-84042002012000006.

Cheng, H., Sinha, A., Cruz, F.W., Wang, X., Edwards, R.L., D'Horta, F.M., Ribas, C.C., Vuille, M., Stott, L.D., and Auler, A.S., 2013, Climate change patterns in Amazonia and biodiversity: Nature Communications, v. 4, doi:10.1038/ncomms2415.

Clement, A.C., Seager, R., and Cane, M.A., 2000, Suppression of El Niño during the midHolocene by changes in the Earth's orbit: Paleoceanography, v. 15, p. 731-737, doi:10.1029/1999PA000466.

Cobb, K.M., Westphal, N., Sayani, H.R., Watson, J.T., Di Lorenzo, E., Cheng, H., Edwards, R.L., and Charles, C.D., 2013, Highly variable El Niño-Southern Oscillation throughout the Holocene: Science, v. 339, p. 67-70, doi:10.1126/science.1228246.

Cohen, M.C.L., Rossetti, D.F., Pessenda, L.C.R., Friaes, Y.S., and De Oliveira, P.E., 2014, Late Pleistocene glacial forest of Humaitá-Western Amazonia: Palaeogeography, Palaeoclimatology, Palaeoecology, p. 11.

Colinvaux, P.A., De Oliveira, P.E., Moreno, J.E., Miller, M.C., and Bush, M.B., 1996, A long pollen record from lowland Amazonia: Forest and cooling in glacial times: Science, v. 274, p. 85-88, doi:10.1126/science.274.5284.85.

Colinvaux, P.A., De Oliveira, P.E., and Patiño, J.E.., 1999, Amazon Pollen Manual and Atlas: Smithsonian Tropical Research Institute, 332 p.

Conroy, J.L., Overpeck, J.T., Cole, J.E., Shanahan, T.M., and Steinitz-Kannan, M., 2008, Holocene changes in eastern tropical Pacific climate inferred from a Galápagos lake sediment record: Quaternary Science Reviews, v. 27, p. 1166-1180, doi:10.1016/j.quascirev.2008.02.015.

Conserva, A.S., and Piedade, M.T.F., 2001, Ciclo de vida e ecologia de Paspalum fasciculatum Willd. Ex. Fluegge (Poaceae), na várzea da Amazônia Central: Acta Amazonica, v. 2, p. 205-220.

Cordeiro, S.A., Souza, C.C., and Mendonza, Z.M.S.H., 2008a, Florestas brasileiras e as mudanças climáticas: Revista Científica Eletrônica de Engenharia Florestal, v. 11, p. $1-20$.

Cordeiro, R.C., Turcq, B., Sifeddine, A., Lacerda, L.D., Silva Filho, E. V., Gueiros, B., Potty, Y.P., Santelli, R.E., Pádua, E.O., and Patchinelam, S.R., 2011, Biogeochemical indicators of environmental changes from $50 \mathrm{Ka}$ to $10 \mathrm{Ka}$ in a humid region of the Brazilian Amazon: Palaeogeography, Palaeoclimatology, Palaeoecology, v. 299, p. 
426-436, doi:10.1016/j.palaeo.2010.11.021.

Cordeiro, R.C., Turcq, B., Suguio, K., Oliveira da Silva, A., Sifeddine, A., and VolkmerRibeiro, C., 2008b, Holocene fires in East Amazonia (Carajás), new evidences, chronology and relation with paleoclimate: Global and Planetary Change, v. 61, p. 4962, doi:10.1016/j.gloplacha.2007.08.005.

Correa, S.B., and Winemiller, K.O., 2014, Niche partitioning among frugivorous fishes in response to fluctuating resources in the Amazonian floodplain forest: Ecology, v. 95, p. 210-224, doi:10.1890/13-0393.1.

Cruz, F.W., Vuille, M., Burns, S.J., Wang, X., Cheng, H., Werner, M., Lawrence Edwards, R., Karmann, I., Auler, A.S., and Nguyen, H., 2009, Orbitally driven east-west antiphasing of South American precipitation: Nature Geoscience, v. 2, p. 210-214, doi:10.1038/ngeo444.

Dansgaard, W. et al., 1993, Evidence for general instability of past climate from a $250-\mathrm{kyr}$ ice-core record: Nature, v. 364, p. 218-220, doi:10.1038/364218a0.

Dantas, M.E.., and Texeira, S.G., 2013, Origem das Paisagens, in JOÃO, X. da S.J., TEIXEIRA, S.G., and FONSECA, D.D.F. eds., .Geodiversidade do Estado do Pará, Belém, CPRM, p. 23-52.

Denevan, W.M., 1996, A Bluff Model of Riverine Settlement in Prehistoric Amazonia: v. 86, p. 654-681, doi:10.1016/B978-0-444-59506-5.50044-4.

Duffin, K.I., Gillson, L., and Willis, K.J., 2008, Testing the sensitivity of charcoal as an indicator of fire events in savanna environments: Quantitative predictions of fire proximity, area and intensity: Holocene, v. 18, p. 279-291, doi:10.1177/0959683607086766.

Ekdahl, E.J., Fritz, S.C., Baker, P.A., Rigsby, C.A., and Coley, K., 2008, Holocene multidecadal- to millennial-scale hydrologic variability on the South American Altiplano: Holocene, v. 18, p. 867-876, doi:10.1177/0959683608093524.

Erickson, C.L., 2000, An artificial landscape-scale fishery in the Bolivian Amazon: Nature, v. 408, p. 190-193, doi:10.1038/35041555.

Erickson, C.L., 2006, The Domesticated Landscapes of the Bolivian Amazon: Time and Complexity in Historical Ecology: Studies in the Neotropical Lowlands, p. 235-278, doi:10.7312/bale13562.

Erickson, C.L., 2008, The Handbook of South American Archaeology:, doi:10.1007/978-0- 
$387-74907-5$.

Ferreira-Júnior, W.G., Schaefer, C.E.G.R., Cunha, C.N., Duarte, T.G., Chieregatto, L.C., and Carmo, F.M.S., 2016, Flood regime and water table determines tree distribution in a forest-savanna gradient in the Brazilian pantanal: Anais da Academia Brasileira de Ciencias, v. 88, p. 719-731, doi:10.1590/0001-3765201620150341.

Ferreira, L.V., 2000, Effects of flooding duration on species richness, floristic composition and forest structure in river margin habitat in Amazonian blackwater floodplain forests: implications for future design of protected areas: Biodiversity \& Conservation, v. 9, p. $1-14$.

Ferreira, L.V., and Stohlgren, T.J., 1999, Effects of river level fluctuation on plant species richness, diversity, and distribution in a floodplain forest in Central Amazonia: Oecologia, v. 120, p. 582-587, doi:10.1007/s004420050893.

Fontes, D., Cordeiro, R.C., Martins, G.S., Behling, H., Turcq, B., Sifeddine, A., Seoane, J.C.S., Moreira, L.S., and Rodrigues, R.A., 2017, Paleoenvironmental dynamics in South Amazonia, Brazil, during the last 35,000 years inferred from pollen and geochemical records of Lago do Saci: Quaternary Science Reviews, v. 173, p. 161180, doi:10.1016/j.quascirev.2017.08.021.

Gagan, M.K., and Thompson, L.G., 2004, Evolution of the Indo-Pacific warm pool and Hadley-Walker circulation since the last deglaciation: Hadley Circulation: Present, Past and Future, v. 21, p. 289-312, doi:10.1007/978-1-4020-2944-8_10.

Gama, J.R.V., Souza, A.L. de, Martins, S.V., and Souza, D.R. de, 2005, Comparação entre florestas de várzea e de terra firme do Estado do Pará: Revista Árvore, v. 29, p. 607616, doi:10.1590/S0100-67622005000400013.

Garcia, S.R., and Kayano, M.T., 2015, Multidecadal variability of moisture and heat budgets of the South American monsoon system: Theoretical and Applied Climatology, v. 121, p. 557-570, doi:10.1007/s00704-014-1265-1.

Glaser, B., and Birk, J.J., 2012, State of the scientific knowledge on properties and genesis of Anthropogenic Dark Earths in Central Amazonia (terra preta de índio): Geochimica et Cosmochimica Acta, v. 82, p. 39-51, doi:10.1016/j.gca.2010.11.029.

Grim, E.C., 1987, CONISS: Textbook of Pollen Analyses: New York, Wiley \& Sons.

Grim, E.C., and Troostheid, C.D., 1994, Tilia 2.00, program for plotting palynological diagrams: Springfield, Illinois State Museum. 
Guimarães, P.R., Galetti, M., and Jordano, P., 2008, Seed dispersal anachronisms: Rethinking the fruits extinct megafauna ate: PLoS ONE, v. 3, doi:10.1371/journal.pone.0001745.

Haug, G.H., 2001, Southward Migration of the Intertropical Convergence Zone Through the Holocene: Science, v. 293, p. 1304-1308, doi:10.1126/science.1059725.

Heckenberger, M.J., Kuikuro, A., Kuikuro, U.T., Russell, J.C., Schmidt, M., Fausto, C., and Franchetto, B., 2003, Amazonia 1492: Pristine forest or cultural parkland? Science, v. 301, p. 1710-1714, doi:10.1126/science.1086112.

Heckenberger, M.J., Russell, J.C., Fausto, C., Toney, J.R., Schmidt, M.J., Pereira, E., Franchetto, B., and Kuikuro, A., 2008, Pre-Columbian urbanism, anthropogenic landscapes, and the future of the Amazon: Science, v. 321, p. 1214-1217, doi:10.1126/science.1159769.

Irion, G., Bush, M.B., Nunes de Mello, J.A., Stüben, D., Neumann, T., Müller, G., Morais de, J.O., and Junk, J.W., 2006, A multiproxy palaeoecological record of Holocene lake sediments from the Rio Tapajós, eastern Amazonia: Palaeogeography, Palaeoclimatology, Palaeoecology, v. 240, p. 523-535, doi:10.1016/j.palaeo.2006.03.005.

Jones, C., and Carvalho, L.M.V., 2002, Active and break phases in the South American monsoon system: Journal of Climate, v. 15, p. 905-914, doi:10.1175/15200442(2002)015<0905:AABPIT>2.0.CO;2.

Julião, G.R., 2007, Riqueza e abundância de insetos galhadores associados ao dossel de florestas de terra firme, várzea e igapó da Amazônia Central: UNIVERSIDADE FEDERAL DO AMAZONAS - UFAM, $144 \mathrm{p}$.

JUNK, W.J., 1989, Flood tolerance and tree distribution in central Amazonian floodplains: ACADEMIC PRESS LIMITED, 47-64 p., doi:10.1016/B978-0-12-353550-4.50012-5.

Junk, W.J., and Piedade, M.T.F., 1993, Herbaceous plantes of the Amazon floodplain near Manaus: species diversity and adaptations to the flood pulse: Amazoniana, v. 12, p. 467-484.

Kanner, L.C., Burns, S.J., Cheng, H., Edwards, R.L., and Vuille, M., 2013, High-resolution variability of the South American summer monsoon over the last seven millennia: Insights from a speleothem record from the central Peruvian Andes: Quaternary Science Reviews, v. 75, p. 1-10, doi:10.1016/j.quascirev.2013.05.008.

Kubitzki, K., 1989, The ecogeographical differentiation of Amazonian inundation forests: 
Plant Systematics and Evolution, v. 162, p. 285-304, doi:10.1007/BF00936922.

Levis, C., de Souza, P.F., Schietti, J., Emilio, T., Pinto, J.L.P. da V., Clement, C.R., and Costa, F.R.C., 2012, Historical Human Footprint on Modern Tree Species Composition in the Purus-Madeira Interfluve, Central Amazonia: PLoS ONE, v. 7, doi:10.1371/journal.pone.0048559.

Liang, B. et al., 2010, Black carbon affects the cycling of non-black carbon in soil: Organic Geochemistry, v. 41, p. 206-213, doi:10.1016/j.orggeochem.2009.09.007.

Lim, S., Ledru, M.P., Valdez, F., Devillers, B., Houngnon, A., Favier, C., and Bremond, L., 2014a, Ecological effects of natural hazards and human activities on the Ecuadorian Pacific coast during the late Holocene: Palaeogeography, Palaeoclimatology, Palaeoecology, v. 415, p. 197-209, doi:10.1016/j.palaeo.2013.12.021.

Lim, S., Ledru, M.P., Valdez, F., Devillers, B., Houngnon, A., Favier, C., and Bremond, L., 2014b, Ecological effects of natural hazards and human activities on the Ecuadorian Pacific coast during the late Holocene: Palaeogeography, Palaeoclimatology, Palaeoecology, v. 415, p. 197-209, doi:10.1016/j.palaeo.2013.12.021.

Liu, Z. et al., 2009, Transient simulation of last deglaciation with a new mechanism for bolling-allerod warming: Science, v. 325, p. 310-314, doi:10.1126/science.1171041.

Maezumi, S.Y., Alves, D., Robinson, M., de Souza, J.G., Levis, C., Barnett, R.L., Almeida de Oliveira, E., Urrego, D., Schaan, D., and Iriarte, J., 2018, The legacy of 4,500 years of polyculture agroforestry in the eastern Amazon: Nature Plants, v. 4, p. 540-547, doi:10.1038/s41477-018-0205-y.

Marengo, J. a, 2006, On the Hydrological Cycle of the Amazon Basin: A Historical Review and Current State-of-the-art Jose Antonio Marengo: Revista Brasileira de Meteorologia, v. 21, p. 1-19.

Marengo, J.A. et al., 2012, Recent developments on the South American monsoon system: International Journal of Climatology, v. 32, p. 1-21, doi:10.1002/joc.2254.

Mayle, F.E., 2000, Millennial-Scale Dynamics of Southern Amazonian Rain Forests: Science, v. 290, p. 2291-2294, doi:10.1126/science.290.5500.2291.

McMichael, C.H., Bush, M.B., Silman, M.R., Piperno, D.R., Raczka, M., Lobato, L.C., Zimmerman, M., Hagen, S., and Palace, M., 2013, Historical fire and bamboo dynamics in western Amazonia (P. Linder, Ed.): Journal of Biogeography, v. 40, p. 299-309, doi:10.1111/jbi.12002. 
McMichael, C.H., Correa-Metrio, A., and Bush, M.B., 2012a, Pre-Columbian fire regimes in lowland tropical rainforests of southeastern Peru: Palaeogeography, Palaeoclimatology, Palaeoecology, v. 342-343, p. 73-83, doi:10.1016/j.palaeo.2012.05.004.

McMichael, C.H., Piperno, D.R., Bush, M.B., Silman, M.R., Zimmerman, A.R., Raczka, M.F., and Lobato, L.C., 2012b, Sparse pre-Columbian human habitation in Western Amazonia: Science, v. 336, p. 1429-1431, doi:10.1126/science.1219982.

Meyers, P.A., 2003, Applications of organic geochemistry to paleolimnological reconstructions: A summary of examples from the Laurentian Great Lakes: Organic Geochemistry, v. 34, p. 261-289, doi:10.1016/S0146-6380(02)00168-7.

Moraes, B.C. De, Maria, J., Carlos, A., and Costa, M.H., 2005, Variação espacial e temporal da precipitação no estado do Pará: Acta Amazonica, v. 35, p. 207-214, doi:10.1590/S0044-59672005000200010.

Moy, C.M., Seltzer, G.O., Rodbell, D.T., and David M. Anderson, 2002, Variability of El Niñ/Southern Oscillation activity at millennial timescales during the Holocene epoch: letters to nature, p. 4.

Moyle, R.G., 2005, Phylogeny and biogeographical history of Trogoniformes, a pantropical bird order: Biological Journal of the Linnean Society, v. 84, p. 725-738, doi:10.1111/j.1095-8312.2005.00435.x.

Neves, W.A., Hubbe, M., and Piló, L.B., 2007, Early Holocene human skeletal remains from Sumidouro Cave, Lagoa Santa, Brazil: History of discoveries, geological and chronological context, and comparative cranial morphology: Journal of Human Evolution, v. 52, p. 16-30, doi:10.1016/j.jhevol.2006.07.012.

De Oliveira, P.E., and Steinitz Kannan, M., 1992, The diatom flora (Bacillariophyceae) of the Cuyabeno Faunistic Reserve, Ecuadorian Amazonia: Nova Hedwigia, v. 54, p. $515-552$.

P.A.Mayewski et al., 2004, Holocene climate variability: Quaternary Research, v. 243-245.

Parolin, P., 2002, Life history and environment of Cecropia latiloba in Amazonian floodplains: Revista de Biologia Tropical, p. 531-545.

Parolin, P.I.A., 2000, Seed mass in Amazonian floodplain forests with contrasting nutrient supplies:

p.

417-428, http://journals.cambridge.org/action/displayAbstract?fromPage=online\&aid=60869. 
Parolin, P., and Ferreira, L., 1998, Are there differences in specific wood gravities between trees in várzea and igapó (Central Amazonia): Ecotropica, v. 4, p. 25-32, http://www.researchgate.net/publication/27282329_Are_there_differences_in_specifi c_wood_gravities_between_trees_in_vrzea_and_igap_(Central_Amazonia)/file/3dee c52210e29a28b7.pdf.

Parolin, P., Oliveira, A.C., Piedade, M.T.F., Wittmann, F., and Junk, W.J., 2002, Pioneer trees in Amazonian floodplains: Three key species form monospecific stands in different habitats: Folia Geobotanica, v. 37, p. 225-238, doi:10.1007/BF02804233.

Parolin, J.A., Rodrigues, W.A., Amaral, I., and Piedade, M.T.F., 2004, Floristic study of igapó ploodplain in Centrel Amazonia, Brazil (Tarumã-Mirim, Rio Negro): Amazoniana, v. 18, p. 29-47.

Piedade, M.T.F., Junk, W., D`Ângelo, S.A., Wittmann, F., Schöngart, J., Barbosa, K.M. do N., and Lopes, A., 2010, Aquatic herbaceous plants of the Amazon floodplains: state of the art and research needed: Acta Limnologica Brasiliensia, v. 22, p. 165-178, doi:10.4322/actalb.02202006.

Piperno, D.R., McMichael, C., and Bush, M.B., 2015, Amazonia and the Anthropocene: What was the spatial extent and intensity of human landscape modification in the Amazon Basin at the end of prehistory? Holocene, v. 25, p. 1588-1597, doi:10.1177/0959683615588374.

Prado, L.F., Wainer, I., Chiessi, C.M., Ledru, M.P., and Turcq, B., 2013, A mid-Holocene climate reconstruction for eastern South America: Climate of the Past, v. 9, p. 21172133, doi:10.5194/cp-9-2117-2013.

Prance, G.T., 1980, A terminologia dos tipos das florestas amazônicas sujreitas a inundação: Acta Amazonica, v. 10, p. 495-504.

Ray, D., Nepstad, D., and Moutinho, P., 2005, Micrometeorological and canopy controls of fire susceptibility in a forested Amazon landscape: Ecological Applications, v. 15, p. 1664-1678, doi:10.1890/05-0404.

Reimer, P. et al., 2013, \{IntCal13\} and \{Marine13\} Radiocarbon Age Calibration Curves 0-50,000 Years cal $\{$ BP\}: Radiocarbon, v. 55, p. 1869-1887.

Rein, B., Lückge, A., Reinhardt, L., Sirocko, F., Wolf, A., and Dullo, W.C., 2005, El Niño variability off Peru during the last 20,000 years: Paleoceanography, v. 20, p. 1-18, doi:10.1029/2004PA001099.

Reis, L.S., Guimarães, J.T.F., Souza-Filho, P.W.M., Sahoo, P.K., de Figueiredo, M.M.J.C., 
de Souza, E.B., and Giannini, T.C., 2017, Environmental and vegetation changes in southeastern Amazonia during the late Pleistocene and Holocene: Quaternary International, v. 449, p. 83-105, doi:10.1016/j.quaint.2017.04.031.

Rodríguez-Zorro, P.A., Turcq, B., Cordeiro, R.C., Moreira, L.S., Costa, R.L., McMichael, C.H., and Behling, H., 2018, Forest stability during the early and late Holocene in the igapó floodplains of the Rio Negro, northwestern Brazil: Quaternary Research (United States), v. 89, p. 75-89, doi:10.1017/qua.2017.99.

Roubik, D.W., and Moreno, J.E., 1991, Pollen and spores of Barro Colorado Island: St. Louis, Missouri, Botanical Garden.

Rowe, H., Hughes, N., and Robinson, K., 2012, The quantification and application of handheld energy-dispersive $\mathrm{x}$-ray fluorescence (ED-XRF) in mudrock chemostratigraphy and geochemistry: Chemical Geology, v. 324-325, p. 122-131, doi:10.1016/j.chemgeo.2011.12.023.

Sá, N. de P., Absy, M.L., and Soares, E.A.A., 2016, Late Holocene paleoenvironments of the floodplain of the Solimões River, Central Amazonia, based on the palynological record of Lake Cabaliana: Acta Botanica Brasilica, v. 30, p. 473-485, doi:10.1590/0102-33062016abb0250.

Salgado-Labouriau, M.L., 1973, Contribuição à Palinologia dos Cerrados. Acad. Bras: Ciências, Rio de Janeiro,.

Salomão, R.D.P., Ima, I., Guimarães, C., li, V., and Suemitsu, C., 2007, As florestas de Belo Monte na grande curva do rio Xingu, Amazônia Oriental The forests of Belo Monte on the great curve of the Xingu River, Eastern Amazon: Ciências Naturais, p. 57-153.

Sandweiss, D.H., Maasch, K.A., Burger, R.L., Richardson, J.B., Rollins, H.B., and Clement, A., 2001, Variation in $\{$ Holocene $\{$ El $\{$ Niño\} frequencies: $\{$ Climate $\}$ records and cultural consequences in ancient \{Peru\}: Geology, v. 29, p. 603-606, doi:10.1130/00917613(2001)029<0603.

Sawakuchi, A.O. et al., 2015, The Volta Grande do Xingu: Reconstruction of past environments and forecasting of future scenarios of a unique Amazonian fluvial landscape: Scientific Drilling, v. 20, p. 21-32, doi:10.5194/sd-20-21-2015.

Schaan, D., Pärssinen, M., Saunaluoma, S., Ranzi, A., Bueno, M., and Barbosa, A., 2012, New radiometric dates for precolumbian (2000-700 b.p.) earthworks in western Amazonia, Brazil: Journal of Field Archaeology, v. 37, p. 132-142, doi:10.1179/0093469012Z.00000000012. 
Scudeller, V. V, Ramos, R.A., and Cruz, M.E.G., 2009, Flora fanerogâmica da floresta de terra firme na RDS Tupé: v. 2, p. 206.

Scudeller, V., and Souza, A., 2009, Florística da mata de igapó na Amazônia Central: Diversidade Biológica, v. 2, p. 97-108.

Ter Steege, H. et al., 2013, Hyperdominance in the Amazonian tree flora: Science, v. 342, doi:10.1126/science.1243092.

Stríkis, N.M., Cruz, F.W., Cheng, H., Karmann, I., Edwards, R.L., Vuille, M., Wang, X., de Paula, M.S., Novello, V.F., and Auler, A.S., 2011, Abrupt variations in South American monsoon rainfall during the Holocene based on a speleothem record from centraleastern Brazil: Geology, v. 39, p. 1075-1078, doi:10.1130/G32098.1.

Theissen, K.M., Dunbar, R.B., Rowe, H.D., and Mucciarone, D.A., 2008, Multidecadal- to century-scale arid episodes on the northern Altiplano during the middle Holocene: Palaeogeography, Palaeoclimatology, Palaeoecology, v. 257, p. 361-376, doi:10.1016/j.palaeo.2007.09.011.

Tolonen, K., 1986, Charred Particle analysis, in Berglund, B.E. ed., Handbook of Holocene Palaeoecology and Palaeohydrology, Chichester, Wiley \& Sons, p. 485-496.

Torres, I.C., Inglett, P.W., Brenner, M., Kenney, W.F., and Reddy, K.R., 2012, Stable isotope $(\delta 13 \mathrm{C}$ and $\delta 15 \mathrm{~N})$ values of sediment organic matter in subtropical lakes of different trophic status: Journal of Paleolimnology, v. 47, p. 693-706, doi:10.1007/s10933-012-9593-6.

Trouet, V., Esper, J., Graham, N.E., Baker, A., Scourse, J.D., and Frank, D.C., 2009, Persistent positive north atlantic oscillation mode dominated the medieval climate anomaly: Science, v. 324, p. 78-80, doi:10.1126/science.1166349.

Umbanhowar, C.E., and McGrath, M.J., 1998, Experimental production and analysis of microscopic charcoal from wood, leaves and grasses: Holocene, v. 8, p. 341-346, doi:10.1191/095968398666496051.

Veloso, H.P., Rangel Filho, A.L.R., and Lima, J.C.A., 1991, Classificação da Vegetação Brasileira Adaptada a um Sistema Universal: 1-124 p., doi:ISBN 85-240-0384-7.

Vuille, M., 1999, Atmospheric circulation over the Bolivian Altiplano during dry and wet periods and extreme phases of the southern oscillation: International Journal of Climatology, v. $19, \quad$ p. 1579-1600, doi:10.1002/(SICl)10970088(19991130)19:14<1579::AID-JOC441>3.0.CO;2-N. 
Vuille, M., Burns, S.J., Taylor, B.L., Cruz, F.W., Bird, B.W., Abbott, M.B., Kanner, L.C., Cheng, H., and Novello, V.F., 2012, A review of the South American monsoon history as recorded in stable isotopic proxies over the past two millennia: Climate of the Past, v. 8, p. 1309-1321, doi:10.5194/cp-8-1309-2012.

WALKER, M. et al., 2009, Formal definition and dating of the GSSP (Global Stratotype Section and Point) for the base of the Holocene using the Greenland NGRIP ice core, and selected auxiliary records: JOURNAL OF QUATERNARY SCIENCE, v. 24, p. 37, doi:10.1002/jqs.1227.

Wang, X., Edwards, R.L., Auler, A.S., Cheng, H., Kong, X., Wang, Y., Cruz, F.W., Dorale, J.A., and Chiang, H.W., 2017, Hydroclimate changes across the Amazon lowlands over the past 45,000 years: Nature, v. 541, p. 204-207, doi:10.1038/nature20787.

Wang, X., Edwards, R., Jr, F.C., Cheng, H., and Auler, A., 2008, Millennial-scale climate variability recorded in Brazilian speleothems: v. 16, p. 1991-1992, http://scholar.google.com/scholar?hl=en\&btnG=Search\&q=intitle:Millennialscale+climate+variability+recorded+in+Brazilian+speleothems\#0 (accessed October 2014).

Warren, A., and G. Sombroek, W., 1967, Amazon Soils. A Reconnaissance of the Soils of the Brazilian Amazon Region: The Geographical Journal, p. 133-550.

Watling, J., Iriarte, J., Mayle, F.E., Schaan, D., Pessenda, L.C.R., Loader, N.J., StreetPerrott, F.A., Dickau, R.E., Damasceno, A., and Ranzi, A., 2017, Impact of preColumbian "geoglyph" builders on Amazonian forests: Proceedings of the National Academy of Sciences, v. 114, p. 1868-1873, doi:10.1073/pnas.1614359114.

Watling, J., Saunaluoma, S., Pärssinen, M., and Schaan, D., 2015, Subsistence practices among earthwork builders: Phytolith evidence from archaeological sites in the southwest Amazonian interfluves: Journal of Archaeological Science: Reports, v. 4, p. 541-551, doi:10.1016/j.jasrep.2015.10.014.

Weng, C., Bush, M.B., and Athens, J.S., 2002, Holocene climate change and hydrarch succession in lowland Amazonian Ecuador: Review of Palaeobotany and Palynology, v. 120, p. 73-90, doi:10.1016/S0034-6667(01)00148-8.

Wittmann, F., Schöngart, J., Montero, J.C., Motzer, T., Junk, W.J., Piedade, M.T.F., Queiroz, H.L., and Worbes, M., 2006, Tree species composition and diversity gradients in white-water forests across the Amazon Basin: Journal of Biogeography, v. 33, p. 1334-1347, doi:10.1111/j.1365-2699.2006.01495.x. 
Worbes, M., Klinge, H., Revilla, J.D., and Martius, C., 1992, On the dynamics, floristic subdivision and geographical distribution of várzea forests in Central Amazonia: Journal of Vegetation Science, v. 3, p. 553-564, doi:10.2307/3235812.

Wozniak, M.C., and Steiner, A.L., 2017, A prognostic pollen emissions model for climate models (PECM1.0): Geoscientific Model Development, v. 10, p. 4105-4127, doi:10.5194/gmd-10-4105-2017. 